\title{
Planococcus spp.: behavior and monitoring in conilon coffee crops
}

\author{
Edinei José Armani Borghi (iD), Gabriel Fornaciari² (iD), Mayara Leite Vieira² (iD), Ronilda Lana Aguiar ${ }^{1}$ (D), Anderson Mathias Holtz ${ }^{1}$ (D), \\ Abraão Carlos Verdin Filho ${ }^{3}$ (D) Marcone Comério $^{3}$ (D) , Saul de Andrade Júnior ${ }^{3}$ (D), José Romário de Carvalho² (iD)
}

${ }^{1}$ Instituto Federal do Espírito Santo/IFES, Colatina, ES, Brasil

${ }^{2}$ Secretaria de Educação do Estado do Espírito Santo, Jerônimo Monteiro, ES, Brasil

${ }^{3}$ Instituto Capixaba de Pesquisa, Assistência Técnica e Extensão Rural/Incaper, Marilândia, ES, Brasil

Contact author: edinei.armani@gmail.com; gabrielfornaciari10@gmail.com; mayaraleitev@gmail.com; ronilda.aguiar@ifes.edu.br; anderson.holtz@ifes.edu.br; verdin.incaper@gmail.com; marcone.comerio@incaper.es.gov.br; saul.eng.agronomo@gmail.com; jromario_carvalho@hotmail.com

Received in September 20, 2020 and approved in March 21, 2021

\section{ABSTRACT}

The damage caused by the citrus mealybug attack, Planococcus spp., on Coffea canephora crops is becoming more and more frequent, and may cause losses close to $100 \%$. Knowledge of aspects related to pest behavior and adoption of methods to monitor crop incidence are important tools for integrated pest management. Thus, the objective was to study the behavior of citrus mealybug along the phenological stages of $C$. canephora and to propose methods to monitor its occurrence in the crops. The study was carried out in an area consisting of adult $C$. canephora plants of the variety Diamante ES 8112 . The study was carried out using four sampling methods: 1) soil and root sampling with a probe; 2) opening small trenches; 3 ) plagiotropic branches and 4) weed sampling. Evaluations were carried out monthly by checking and confirming the presence of citrus mealybug in the sampled regions. The information obtained was used to describe the behavior of citrus mealybug and to analyze the applicability of the monitoring methods studied. In the absence of the reproductive phase, citrus mealybug lodges in the root system of coffee and weeds, in the region close to the colon, moving to the aerial part of the plants (rosettes) at the beginning of the flowering of the crop. Probe sampling was not efficient, while opening small trenches is a difficult procedure and causes damage to the root system of the coffee tree. The sampling of plagiotropic branches and weeds allows the monitoring of citrus mealybug during all the phenological phases of $C$. canephora.

Key words: Coffea canephora; Integrated pest management; Citrus mealybugs; Sampling; Weeds.

\section{INTRODUCTION}

The socioeconomic development of Brazil is favored by the financial movement provided by the production and commercialization of coffee. According to the first survey by the National Supply Company (Companhia Nacional de Abastecimento - CONAB, 2020), in 2019 the Brazilian coffee production was approximately 49 million bags benefited, with growth forecast of $15.9 \%$ to $25.8 \%$ for the year 2020 . Thus, the country has been constantly occupying the position of the world's largest coffee producer (Nakayama et al., 2020).

Coffee production in the state of Espírito Santo, Brazil, faces challenges in the productive sector that compromise crop productivity and the achievement of more relevant results in the national scenario (Fornazier et al., 2019; Fornazier et al., 2018). In recent years, one of the greatest challenges faced by coffee growers has been the incidence of citrus mealybug in conilon coffee plantations (Coffea canephora Pierre ex. Froehner), this is due to the direct effects caused to productivity and difficulty in carrying out pest control, promoting increased production costs and decreased profitability with the activity (Fornazier et al., 2019).

According to Fornazier et al. (2019) and Fornazier et al. (2018), the damage caused in coffee trees by the attack of citrus mealybug of the species Planococcus citri Risso and Planococcus minor Maskell (Hemiptera: Pseudococcidae) is becoming more and more frequent. Damage can be caused by both nymphs and adult females of citrus mealybug that suck sap and cause flower buds, flowers and fruits to fall in the early stages of development. In later attacks, withering and hindering fruit development occur. In addition, the mealybug citrus can cause the coffee tree to rot, close to the ground, which may favor the entry of pathogenic microorganisms. In highly infested crops, losses can reach close to $100 \%$ of production (Fornazier et al., 2019; SantaCecília et al., 2007).

Knowledge of aspects related to the behavior of citrus mealybug in conilon coffee as well as the adoption of methods to monitor its incidence in crops are essential tools for the execution of an Integrated Pest Management Program. However, there is a lack of scientific studies that demonstrate such information, making it necessary to carry out studies that allow better knowledge of this insect pest and that seek efficient alternatives to carry out its monitoring in conilon coffee crops. In this context, the objective of this work was to study the behavior of citrus mealybug along the phenological stages of conilon coffee and to propose methods to monitor its occurrence in the fields. 


\section{MATERIAL AND METHODS}

The study was carried out at the Experimental Farm of Marilândia of the Capixaba Institute of Research, Technical Assistance and Rural Extension (INCAPER), located in the municipality of Marilândia, ES, Brazil, geographic coordinates of $19^{\circ} 24^{\prime} 14^{\prime \prime}$ south latitude, $40^{\circ} 32$ ' 13 ' west longitude, altitude of 168 meters, Northwest region of the state of Espírito Santo (Figure 1).

The study lasted 12 months, starting in August 2018. During this period, climatic conditions were monitored using the automatic climatological station at Experimental Farm in Marilândia, with maximum, minimum and average temperature values of $36{ }^{\circ} \mathrm{C}$ being recorded, $10{ }^{\circ} \mathrm{C}$ and $24.7{ }^{\circ} \mathrm{C}$, respectively, and accumulated precipitation of $826.20 \mathrm{~mm}$ (Figure 1). In general, the region's climate is classified as Tropical Aw (Köppen, 1936; Peel; Finlayson; Mcmahon, 2007), with irregular rainfall and high temperatures.

The monitored area consisted of adult plants of C. canephora of the variety Diamante ES 8112, with 13 clones (V1 to V12). The history of the area revealed that the V12 clones had high infestations of citrus mealybugs in previous years, being, therefore, our object of study. The study area did not receive any control methods during the study.

Monitoring was carried out monthly using four sampling methods, namely: 1) soil and root sampling using an $0.084 \mathrm{~m}$ diameter probe; 2 ) opening of small trenches close to the plant's neck; 3) sampling of plagiotropic branches; and 4) weed sampling.

The evaluations were carried out in 10 plants of $C$. canephora V12 clones chosen at random, by means of a draw, totaling 120 plants evaluated during the monitoring period. Initially, soil and root samples were collected with the probe at 0.15 and $0.30 \mathrm{~m}$ away from the plant's neck and at depths of $0-0.10 \mathrm{~m}$ and $0.10-0.20 \mathrm{~m}$, on both sides facing the planting spacing (Figure 2A). Then, small trenches were opened with dimensions of $0.40 \mathrm{x} 0.40 \mathrm{x}$ $0.20 \mathrm{~m}$, removing excess soil with the help of a brush and checking for the presence of citrus mealybugs in the neck and root system of the coffee tree (Figure 2B). Finally, plagiotropic branches were sampled in the upper, median and lower thirds of the selected plants (Figure 2C) and weeds were collected between the lines of the coffee tree by manual removal.

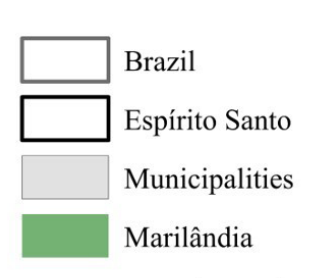

- $\quad$ Experimental Farm of INCAPER
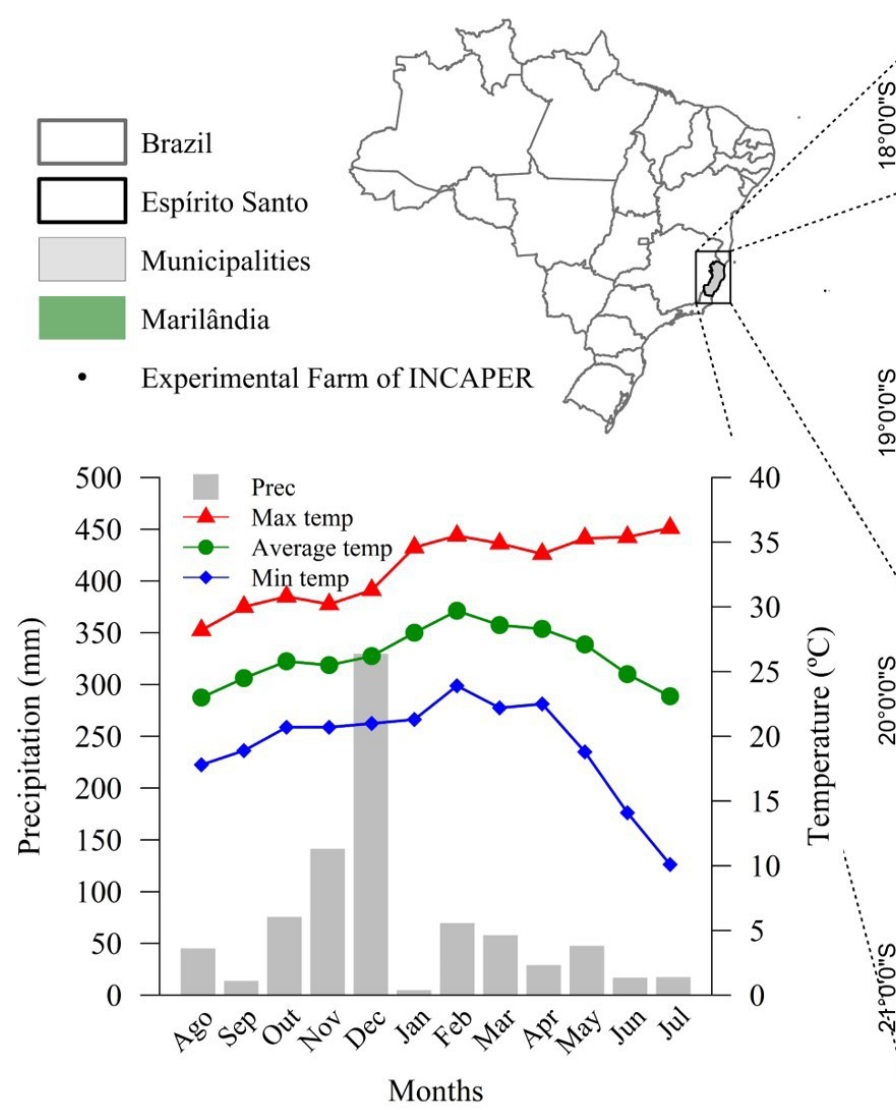

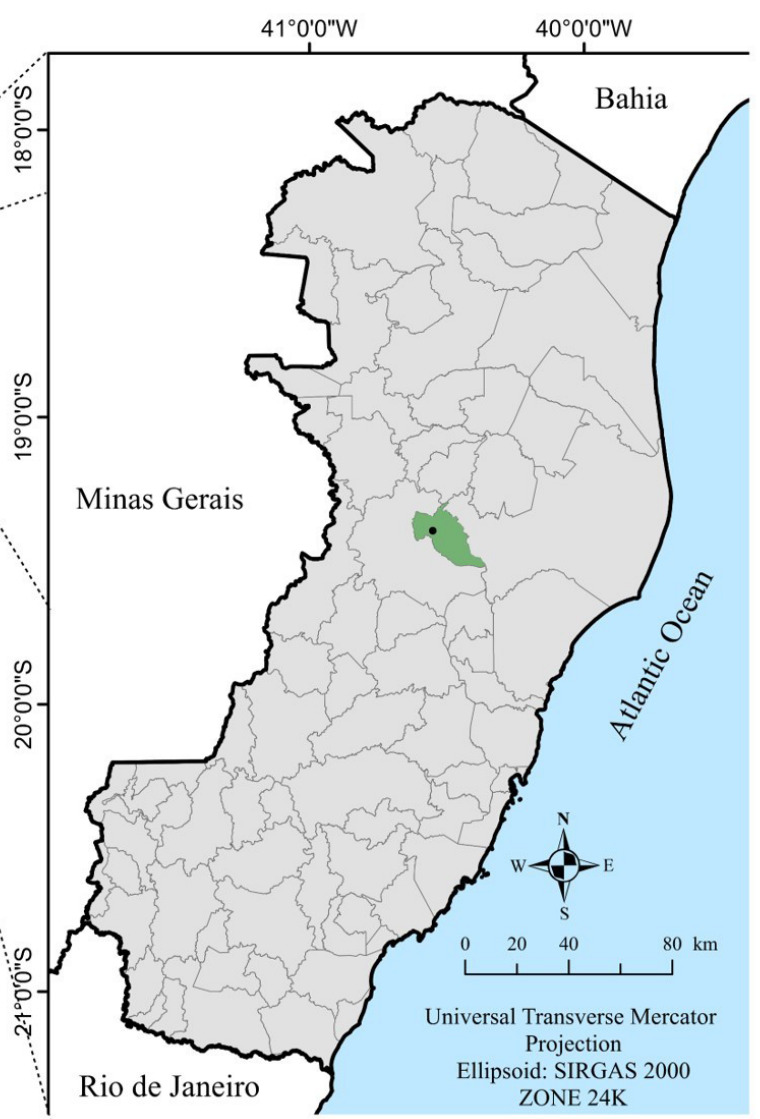

Figure 1: Location of the Experimental Farm of Marilândia of the Capixaba Institute of Research, Technical Assistance and Rural Extension (INCAPER), temperature variations $\left({ }^{\circ} \mathrm{C}\right)$ and precipitation ( $\mathrm{mm}$ month ${ }^{-1}$ ) between August 2018 and July 2019 , Marilândia, ES, Brazil. 

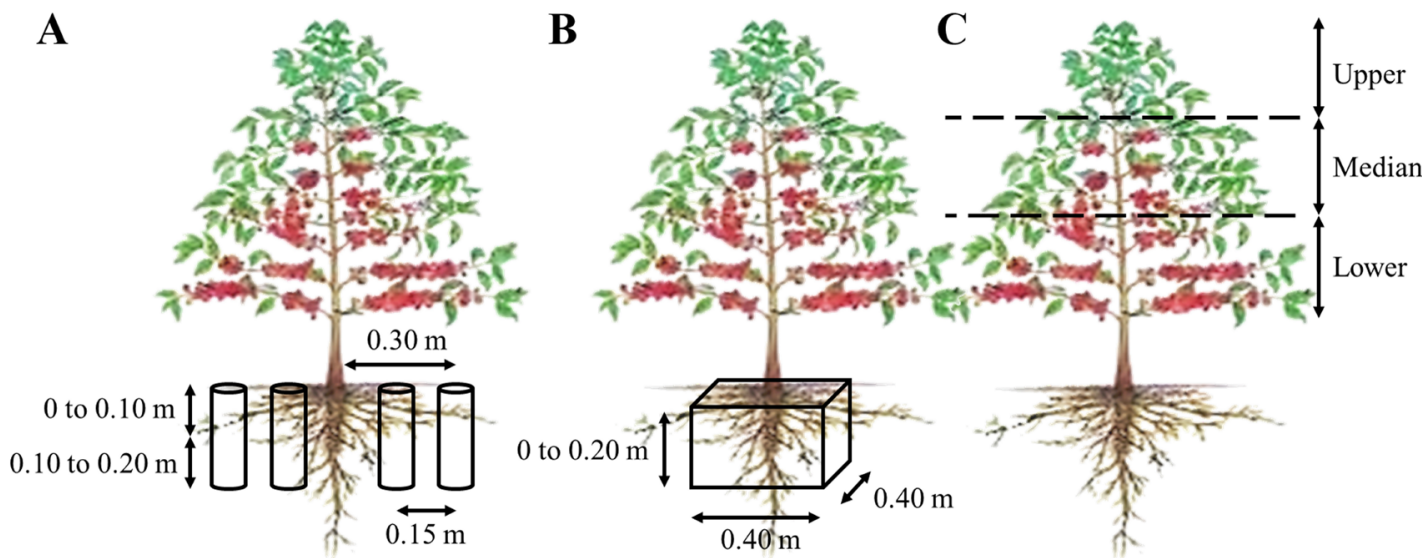

Figure 2: Illustrative scheme for monitoring citrus mealybug in conilon coffee by sampling with probe (A), opening small trenches (B) and plagiotropic branches (C).

The verification of the presence of citrus mealybugs in the field was carried out with the aid of manual magnifiers (10x magnification). Upon checking the presence of citrus mealybugs in the sampled regions, the insects were collected and placed in test tubes containing $60 \%$ alcohol solution $\left(\mathrm{v} \mathrm{v}^{-1}\right)$. The test tubes were sent to the Entomology and Agricultural Acarology Laboratory of the Federal Institute of Espírito Santo - Campus Itapina (Ifes - Itapina) for proper identification of species. The identification of the specimens was performed according to the description presented by Williams and Willink (1992). Sample slides were prepared and subsequently observed under a microscope to compare the taxonomic key of the species.

Upon confirming by laboratory analysis that the mealybugs collected were of the species $P$. citri or P. minor, it was considered that the pest was definitely present at the place of origin and at the time evaluated. The results obtained were used to describe the behavior of citrus mealybug in the cultivation of C. canephora and to analyze the applicability of the monitoring methods adopted in this study. As the specimen identification process was not feasible at the field level, individual counting and sorting by species was not performed. Thus, we consider both species as citrus mealybug and only monitor the occurrence in C. canephora clone V12 plants.

The frequency of occurrence data was subjected to comparisons using pairwise contrast using the Chi-square test $(\mathrm{p}<0.05)$, within each month. The analyze was performed by the version 3.4 of the $\mathrm{R}$ computational application ( $\mathrm{R}$ Development Core Team, 2017).

\section{RESULTS}

Through probe sampling, there was no presence of citrus mealybug in the soil and roots, regardless of the distance, depth and time of sampling (Table 1). On the other hand, it was found through the opening of small trenches the presence of citrus mealybug in the root system close to the region of the plant neck between the end of the granulation phase and the vegetative period of the coffee tree.

Regarding to weed sampling, it is noted that during the study period citrus mealybug was observed only in the root system (Table 1), mainly in the roots close to the neck region.

Through the sampling of plagiotropic branches, the presence of citrus mealybug was found between the flowering and maturation phases (Table 1), affecting the upper, median and lower thirds of the coffee tree, where the insects lodged mainly inside the rosettes causing the fall and mummification of the fruits.

The frequency of occurrence of Planococcus spp. showed a difference in relation to the sampling methods (Figure 3). From August to March sampling in plagiotropic branches and in the root system of weeds differed from the small trench method (Table 2). In April the sampling by small trenches differed only from the sampling of plagiotropic branches, and as of May the sampling by small trenches was higher. Regardless of the time, sampling in the weed root system showed an incidence of Planococcus spp. (Figure 3), with values equal to or greater than $20 \%$. For the sampling of plagiotropic branches, we verified incidences of up to $80 \%$ at the end of the reproductive period (Figure 3).

When analyzing the sampling of plagiotropic branches in isolation based on their location (Figure 4), we verified that there was a variation in the frequency of occurrence between the thirds of the limited aerial part of the plant, with an increase in incidence over time during the reproductive period of the culture (August to April), but without statistical difference between them $(p>0.05)$.

\section{DISCUSSION}

The sampling method of small trenches proved that citrus mealybug descends to the root region of the coffee plant 
in the absence of the reproductive period of the crop, but does not go deeper into the soil, remaining in the region of the plant's neck. Such observations suggest that the citrus mealybug does not inhabit the soil and the entire root extension of the coffee tree, lodging predominantly in the roots close to the plant neck region, complementing the observations by Santa-Cecília et al. (2007).

Fornazier et al. (2018), also noted the preference of citrus mealybug for the root system of weeds associated with conilon coffee, proving that this is a place of refuge. Fornaciari et al. (2020) found 17 species of host weeds of citrus mealybug in conilon coffee crops, distributed within the botanical families: Asteraceae, Malvaceae, Poaceae, Amaranthaceae, Cyperaceae, Solanaceae, Commelinaceae, Portulacaceae and Cucurbitaceae, demonstrating the potential of weeds as host and source of inoculum for infestations during the flowering and fruiting phase, similar to that observed by Bastos et al. (2007) in cotton growing areas with the occurrence of $P$. minor.

The absence of nymphs or adults of the citrus mealybug in the canopy of the conilon coffee tree between the months of April and September is due to the movement of insects to shelters during the winter period (Fornazier et al., 2019;

Table 1: Presence and absence of citrus mealybug according to the sampling method and phenological phase of $C$. canephora V12 clones, between August 2018 and July 2019, Marilândia, ES, Brazil.

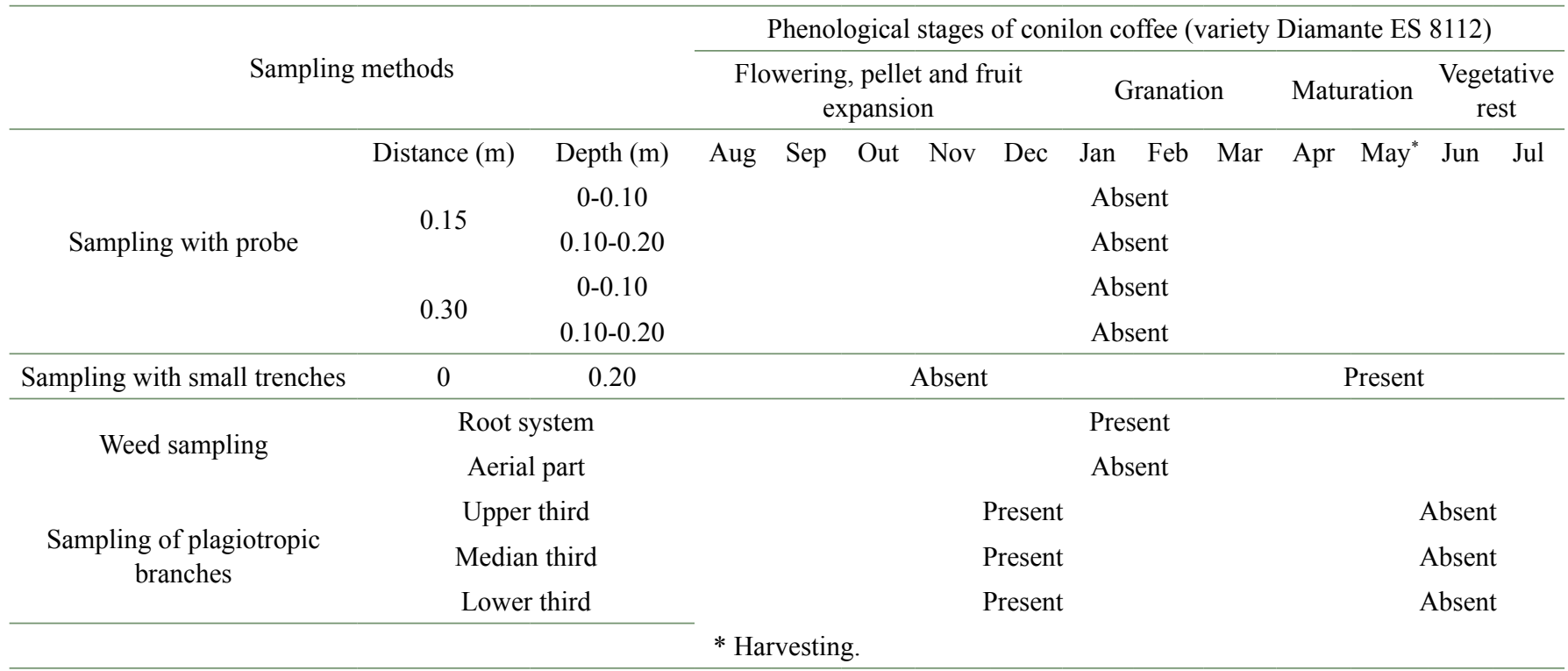

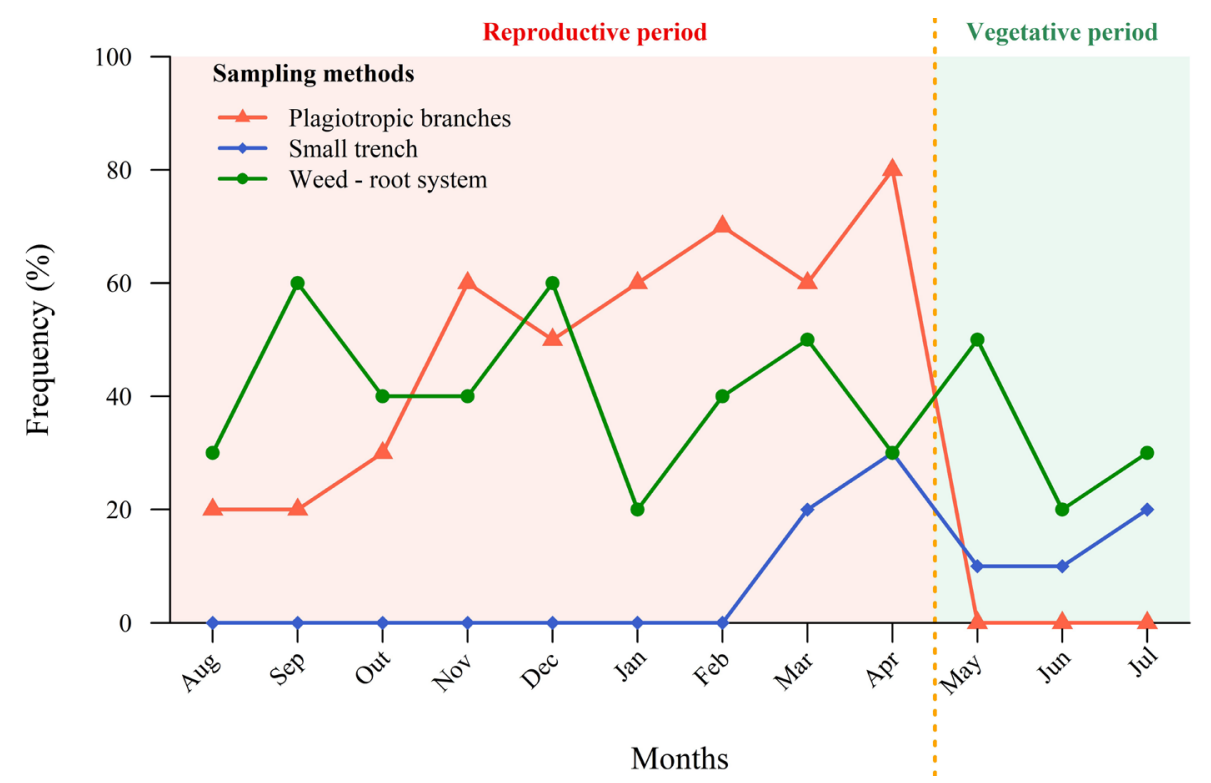

Figure 3: Frequency of incidence of citrus mealybug in Coffea canefora by different sampling methods, between August 2018 and July 2019, Marilândia, ES, Brazil. 
Fornazier et al., 2018). The mealybug citrus lodges in the roots during the dry season of the year and with the beginning of the rains and irrigations to induce flowering they rise to the aerial part of the coffee tree, attacking the flowers, pellets and the base of the fruits (Fornazier et al., 2018; Fornazier et al., 2019; Santa-Cecília et al., 2007). In addition, a downward migration of citrus mealybug has been reported in conditions of low air temperatures, with a predominance of nymphs in the coffee root system at temperatures close to $15^{\circ} \mathrm{C}$, while with the temperature rise at levels close to $30^{\circ} \mathrm{C}$, insects demonstrate a predominance of infestation in the upper part of the plants (Santa-Cecilia et al., 2011). Similarly, in citrus crops in the Arizona-USA region, citrus mealybugs such as $P$. citri hibernate in the upper roots, trunks and lower branches of the tree, where they lay eggs that hatch in April and infest the reproductive parts (Kerns; Wright; Loghry, 2001). In vines in northern Spain the population of adult females and first and second stage nymphs are sheltered in the lower part of the trunk and in woody parts of the plants,

Table 2: Comparison between Planococcus spp. in Coffea canephora crops in different months, Marilândia, ES, Brazil.

\begin{tabular}{|c|c|c|c|}
\hline \multirow{4}{*}{ Mounths/years } & \multicolumn{3}{|c|}{ Contrasts between sampling methods* } \\
\hline & Plagiotropic branches & Plagiotropic branches & Small trench \\
\hline & $v s$ & $v s$ & $v s$ \\
\hline & Small trench & Weed - root system & Weed - root system \\
\hline Aug/2018 & $\chi^{2}=20.00 . p<0.001$ & $\chi^{2}=2.00 \cdot p=0.1573^{\mathrm{NS}}$ & $\chi^{2}=30.00 . \mathrm{p}<0.001$ \\
\hline Sep/2018 & $\chi^{2}=20.00 . p<0.001$ & $\chi^{2}=20.00 . p<0.001$ & $\chi^{2}=60.00 . p<0.001$ \\
\hline Out/2018 & $\chi^{2}=30.00 . p<0.001$ & $\chi^{2}=1.43 . p=0.232^{\mathrm{NS}}$ & $\chi^{2}=40.00 . p<0.001$ \\
\hline Nov/2018 & $\chi^{2}=60.00 . p<0.001$ & $\chi^{2}=4.00 . p=0.0455$ & $\chi^{2}=40.00 . \mathrm{p}<0.001$ \\
\hline $\mathrm{Dec} / 2018$ & $\chi^{2}=50.00 . p<0.001$ & $\chi^{2}=0.91 \cdot p=0.3404^{\mathrm{NS}}$ & $\chi^{2}=60.00 . p<0.001$ \\
\hline Jan/2019 & $\chi^{2}=60.00 . p<0.001$ & $\chi^{2}=20.00 . p<0.001$ & $\chi^{2}=20.00 . \mathrm{p}<0.001$ \\
\hline $\mathrm{Feb} / 2019$ & $\chi^{2}=60.00 . p<0.001$ & $\chi^{2}=8.18 \cdot p=0.004$ & $\chi^{2}=40.00 . \mathrm{p}<0.001$ \\
\hline Mar/2019 & $\chi^{2}=20.00 . p<0.001$ & $\chi^{2}=0.91 \cdot p=0.3404^{\mathrm{NS}}$ & $\chi^{2}=12.85 . \mathrm{p}<0.001$ \\
\hline Apr/2019 & $\chi^{2}=22.73 . p<0.001$ & $\chi^{2}=22.73 . p<0.001$ & $\chi^{2}=0.00 . p=1.000^{\mathrm{NS}}$ \\
\hline May/2019 & $\chi^{2}=10.00 . p=0.0015$ & $\chi^{2}=50.00 . p<0.001$ & $\chi^{2}=26.67 . p<0.001$ \\
\hline Jun/2019 & $\chi^{2}=10.00 . p=0.0015$ & $\chi^{2}=20.00 . p<0.001$ & $\chi^{2}=3.33 . p=0.0678^{\mathrm{NS}}$ \\
\hline $\mathrm{Jul} / 2019$ & $\chi^{2}=20.00 . p<0.001$ & $\chi^{2}=30.00 . p<0.001$ & $\chi^{2}=2.00 \cdot p=0.1573^{\mathrm{NS}}$ \\
\hline
\end{tabular}

${ }^{*}$ Chi-square test.

Ns Not significant.

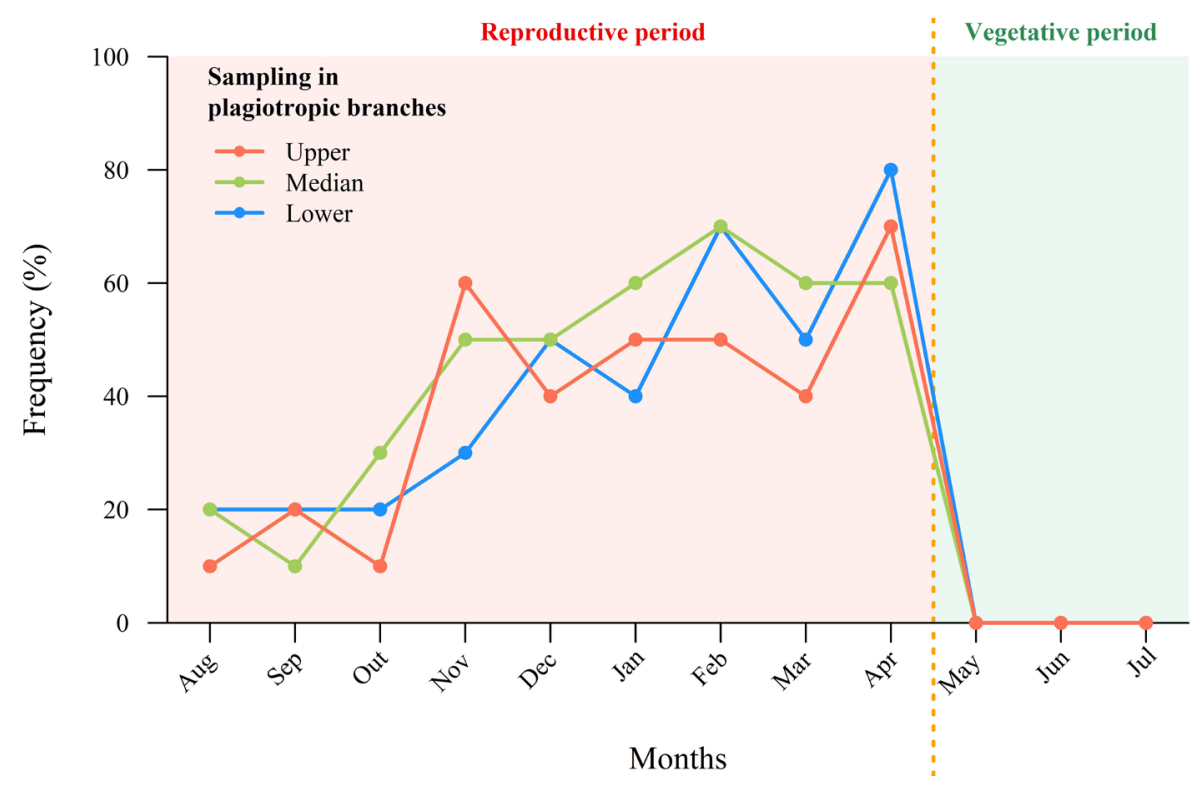

Figure 4: Frequency of incidence of citrus mealybug in Coffea canefora in the sampling of plagiotropic branches (lower, median and upper), between August 2018 and July 2019, Marilândia, ES, Brazil. 
showing a peak population of first and second stage nymphs in the summer (Cid et al., 2010).

Therefore, with the results presented in this study, it is possible to state that in the absence of flowers and fruits (postharvest and vegetative rest), which coincide with the driest period of the year and lower temperatures, citrus mealybug is housed in the root system of coffee and weeds, in the region close to their neck, moving to the aerial part of the plants (rosettes) during the reproductive phases of the conilon coffee tree.

Regarding the sampling methods, except for sampling with a probe and the aerial part of the weeds, all showed the potential to monitor citrus mealybug in areas cultivated with conilon coffee. However, it is noteworthy that the evaluation of the root system through small trenches is a procedure that requires greater technique and execution time, in addition, it promotes damage to the root system of the coffee tree. Alternatively, sampling plagiotropic branches and weeds (in the root region) are easy to perform methods and together they allow the monitoring of citrus mealybug during all phenological phases of the conilon coffee tree.

The weed sampling process should be carried out, preferably, in the species Bidens pilosa L. and Ageratum conyzoides L. because they are easily found in conilon coffee plantations and for demonstrating greater susceptibility to the occurrence of citrus mealybug (Fornaciari et al., 2020; Fornazier et al., 2019).

\section{CONCLUSION}

When the conilon coffee tree does not have reproductive structures, the citrus mealybug lodges in the root system of the coffee tree and weeds, in the region close to the stem, moving to the aerial part of the plants (rosettes) at the beginning of the flowering of the crop.

Probe sampling is not efficient for monitoring rosette scale, while opening small trenches is a difficult procedure to perform and causes damage to the coffee root system.

Sampling of plagiotropic branches and weeds allows monitoring of citrus mealybug during all phenological phases of the conilon coffee.

\section{ACKNOWLEDGEMENTS}

The authors would like to thank the Federal Institute of Education, Science and Technology of Espírito Santo Campus Itapina (Ifes) and the Capixaba Institute of Research, Technical Assistance and Rural Extension (Incaper) for the technical and logistical support to carry out this work.

\section{REFERENCES}

BASTOS, C. S. et al. Ocorrência de Planococcus minor maskell (Hemiptera: Pseudococcidae) em algodoeiro no
Nordeste do Brasil. Neotropical Entomology, 36(4):625628, 2007.

CID, M. et al. Citrus mealybug (Hemiptera: Pseudococcidae) movement and population dynamics in an arbortrained vineyard. Journal of Economic Entomology, 103(3):619-630, 2010

COMPANHIA NACIONAL DE ABASTECIMENTO CONAB. Acompanhamento da safra brasileira de café - Safra 2020 - Primeiro levantamento. CONAB, Brasília - DF. Available in: <https://www.conab.gov.br/ info-agro/safras/cafe>. Access in: October, 23, 2020.

FORNACIARI, G. et al. Survey of potentially host weeds of Planococcus spp. in Coffee crops. International Journal of Advanced Engineering Research and Science, 7(5):333-337, 2020.

FORNAZIER, M. J. Integrated pest management in conilon coffee. In: FERRÃO, R. G. et al. Conilon Coffee. Incaper, Vitória, ES, p.493-533, 2019.

FORNAZIER, M. J. Manejo da cochonilha-da-roseta em café Conilon. N. 256. 2018. 10p.

KERNS, D.; WRIGHT, G.; LOGHRY, J. Citrus mealybug (Planococcus citri), citrus arthropod pest management in Arizona. Tucson. 2001. 4p. Available in: $<$ https://cals. arizona.edu/crop/citrus/insects/citrusmealy.pdf $>$. Access in: June, 10, 2020.

KÖPPEN, W. Das geographische systemder klimate. In: KÖPPEN, W.; GEIGER, M. R. (Eds.). Handbuch der Klimatologie. Borntraeger, Berlin, 1936. 44p.

NAKAYAMA, C. C. Microorganism succession at different coffee drying stages and its influence on the beverage. Brazilian Journal of Development, 6(1):2402-2418, 2020.

PEEL, M. C.; FINLAYSON, B. L.; MCMAHON, T. A. Updated world map of the Köppen-Geiger climate classification. Hydrology and Earth System Sciences, 11(5):1633-1644, 2007.

R DEVELOPMENT CORE TEAM. R: A language and environment for statistical computing, R Foundation for Statistical Computing, version 3.4. 2017. Available in: <https://www.R-project.org/>. Access in: August, 1, 2017.

SANTA-CECÍLIA, L. V. C.; PRADO, E.; SOUSA, A. L. V. Influência da temperatura na distribuição vertical da cochonilha-branca, Planococcus citri (risso) (Hemiptera: Pseudococcidae) em plantas de café. Arquivos do Instituto Biológico, 78(4):619-622, 2011. 
SANTA-CECÍLIA, L. V. C. Cochonilhas-farinhentas em cafeeiros: Bioecologia, danos e métodos de controle. Boletim técnico, n. 79. 2007. 48p.
WILLIAMS, D. J.; WILLINK, M. C. G. de. Mealybugs of central and south America. CAB International London, England. 1992. 635p. 